\title{
Cervical Microglandular Hyperplasia
}

National Cancer Institute

\section{Source}

National Cancer Institute. Cervical Microglandular Hyperplasia. NCI Thesaurus. Code C127931.

A benign endocervical gland proliferation characterized by the presence of closely packed glands composed of columnar to cuboidal cells with subnuclear mucin vacuoles. It is associated with progestins or pregnancy. 